Metallophysics and Advanced Technologies

Металофіз. новітні технол.

Metallofiz. Noveishie Tekhnol.

2019, vol. 41, No. 5, pp. 607-620

https://doi.org/10.15407/mfint.41.05.0607

Reprints available directly from the publisher
(C) 2019 G. V. Kurdyumov Institute for Metal Physics, National Academy of Sciences of Ukraine Published by license under the G. V. Kurdyumov Institute for Metal PhysicsN.A.S. of Ukraine Publishers imprint. Printed in Ukraine.

PACS numbers: 46.55.+d, 61.66.Dk, 61.72.-y, 62.20.Qp, 81.05.-t, 81.40.Ef, 81.40.Pq

\title{
Effect of Heat Treatments on the Microstructure and Wear Resistance of a Modified Hadfield Steel
}

\section{S. Ayadi and A. Hadji}

\author{
Badji Mokhtar University, \\ Laboratory of Foundry 1, \\ B.P.12 Annaba, \\ CP 23000 Annaba, Algeria
}

In this study, the effect of heat treatments on the microstructure and wear resistance of Hadfield steel with different $\mathrm{Cr}+\mathrm{Ni}$ contents is investigated. Hadfield steel with $1.2 \%$ wt. $\mathrm{C}$ and $12 \%$ wt. $\mathrm{Mn}$ is melted in an electric arc furnace. Added elements $(\mathrm{Cr}$ and $\mathrm{Ni}$ ) are crushed and added as ultra-fine powders of ferro-alloyed composition in a well heated ladle. Two series of heat treatments are applied: one at $1100^{\circ} \mathrm{C}$ and the other at $1050^{\circ} \mathrm{C}$. The microstructure of these steels is analysed using optical microscopy, scanning electron microscopy and X-ray diffraction. The Rockwell $\mathrm{C}$ hardness and the Vickers microhardness are measured at ambient temperature. The wear behaviour of all samples in as-cast and heat treated states is studied using pinon-disk wear tests. The obtained results show that the microstructure of the as-cast Hadfield steel samples consists of an austenitic matrix and complex carbides precipitated at the grain boundaries. Increase in the $\mathrm{Cr}+\mathrm{Ni}$ content refines the structure that improves the hardness and the wear resistance. In the heat-treated state, the microstructure reveals two distinct phases: martensite and retained austenite. The increase of heat treatment temperature favours the martensitic transformation, which positively affects the hardness and wear behaviour of studied steels.

Key words: Hadfield steel, chromium, nickel, heat treatment, microstructure, wear resistance.

Дану роботу присвячено досліджено впливу термічних обробок на мікроструктуру та зносостійкість сталі Гадфільда 3 різним вмістом $\mathrm{Cr}+\mathrm{Ni}$.

Corresponding author: Souad Ayadi

E-mail: ayadisouad14@gmail.com

Citation: S. Ayadi and A. Hadji, Effect of Heat Treatments on the Microstructure and Wear Resistance of a Modified Hadfield Steel, Metallofiz. Noveishie Tekhnol., 41, No. 5: 607-620 (2019), DOI: 10.15407/mfint.41.05.0607. 
Сталь Гадфільда із 1,2\% мас. С та $12 \%$ мас. Mn було виплавлено в електродуговій печі. Додаткові елементи (Cr i Ni) подрібнювали і додавали у вигляді ультрадисперсних порошків феросплавного складу в добре нагрітий ківш. Було проведено дві серії термічних обробок: одна при $1100^{\circ} \mathrm{C}$, a інша - при $1050^{\circ} \mathrm{C}$. Мікроструктура одержаних сталей аналізувалася за допомогою методів оптичної мікроскопії, сканувальної електронної мікроскопії та рентгенівської дифракції. Твердість за Роквеллом (шкала С) та мікротвердість за Віккерсом вимірювалися за температури навколишнього середовища. Дослідження зносостійкості всіх зразків як у литому стані, так і після термообробки проводилися за допомогою тестів на знос на штифтодисковій машині. Отримані результати показали, що мікроструктура литих зразків досліджуваної сталі Гадфільда характеризується наявністю аустенітної матриці та складних карбідів, що осаджуються на границях зерен. Збільшення вмісту $\mathrm{Cr}+\mathrm{Ni}$ покращує структуру, підвищуючи твердість і зносостійкість. У термічно обробленому стані мікроструктурні дослідження виявляють дві різні фази: мартенсит і залишковий аустеніт. Підвищення температури термообробки сприяє мартенситному перетворенню, що позитивно впливає на твердість і зносостійкість досліджуваних сталей.

Ключові слова: сталь Гадфільда, хром, нікель, термообробка, мікроструктура, зносостійкість.

Работа посвящена исследованию влияния термических обработок на микроструктуру и износостойкость стали Гадфильда с различным содержанием $\mathrm{Cr}+\mathrm{Ni}$. Сталь Гадфильда с 1,2\% масс. С и $12 \%$ масс. Mn была выплавлена в электродуговой печи. Дополнительные элементы (Cr и Ni) измельчали и добавляли в виде ультрадисперсных порошков ферросплавного состава в хорошо нагретый ковш. Было проведено две серии термических обработок: одна при $1100^{\circ} \mathrm{C}$, а другая - при $1050^{\circ} \mathrm{C}$. Микроструктура полученных сталей анализировалась методами оптической микроскопии, сканирующей электронной микроскопии и рентгеновской дифракции. Твёрдость по Роквеллу (шкала С) и микротвёрдость по Виккерсу измерялись при температуре окружающей среды. Исследования износостойкости всех образцов как в литом состоянии, так и после термообработки проводились при помощи тестов на износ на штифтодисковой машине. Полученные результаты показали, что микроструктура литых образцов исследуемой стали Гадфильда характеризуется наличием аустенитной матрицы и сложных карбидов, осаждающихся на границах зёрен. Увеличение содержания $\mathrm{Cr}+\mathrm{Ni}$ улучшает структуру, повышая твёрдость и износостойкость. В термически обработанном состоянии микроструктурные исследования обнаруживают две разные фазы: мартенсит и остаточный аустенит. Повышение температуры термообработки способствует мартенситному превращению, что положительно влияет на твёрдость и износостойкость исследуемых сталей.

Ключевые слова: сталь Гадфильда, хром, никель, термообработка, микроструктура, износостойкость.

(Received September 3, 2018; in final version, February 12, 2019) 


\section{INTRODUCTION}

The high manganese austenitic steel containing 1-1.4\% wt. C and 10$14 \%$ wt. Mn or Hadfield steel was invented in 1882 by Sir Robert Hadfield. Its interesting properties, e.g. high ductility, high toughness, excellent wear resistance and high strain hardening capacity, made it widely used in mining, railways and in the manufacture of destruction impact and hammer crushers [1-5].

The as-cast microstructure of Hadfield steel is characterized by an austenitic matrix and precipitates of manganese alloyed cementite [6]. The austenitic structure imparts a wear sensibility to the Hadfield steel, which limits its life. Nowadays, the addition of alloying elements, such as chromium, vanadium, nickel, molybdenum, aluminium, nitrogen is used to improve its mechanical properties [7-10].

The addition of austenite stabilizing elements, i.e. nickel, raises the hardness and wear resistance without changing the microstructure; carbide-forming elements enhance the precipitation of complex carbides in castings, mainly at the grain boundaries. During solidification of castings, this heterogeneity of structure induces formation of stresses and may lead to brittle fracture [11-15].

Dissolution of these carbides requires a particular heat treatment (holding at $1000^{\circ} \mathrm{C}$ to $1100^{\circ} \mathrm{C}$ and cooling in the water). The obtaining of the enriched austenite free of precipitates at grain boundaries affects positively hardness and wear resistance [16-19].

Added elements and heat treatments play an important role in formation of microstructure, as well as hardness and wear resistance of the Hadfield steel. In this paper, the effect of chromium and nickel content on the microstructure and wear behaviour of Hadfield steel has been studied.

\section{EXPERIMENTAL PROCEDURE}

\subsection{Samples Preparation and Heat Treatments}

The experimental alloys were melted in a medium frequency electric arc furnace. $\mathrm{Cr}$ and $\mathrm{Ni}$ were crushed and added as ultra-fine powders of ferroalloyed elements in a well-heated ladle. Thereafter the alloys were cast into furane resin sand molds in the form of cylindrical specimens of $100 \mathrm{~mm}$ in length and $50 \mathrm{~mm}$ in diameter.

In order to evaluate the effect of heat treatments on $\mathrm{Cr}+\mathrm{Ni}$ alloyed Hadfield steel, the samples were subjected to two heat treatments, one at $1100^{\circ} \mathrm{C}$ and other at $1050^{\circ} \mathrm{C}$ followed by quenching in water. The first heat treatment consists of heating the samples at temperatures of 600,1080 and $1100^{\circ} \mathrm{C}$ with the heating rate of $6^{\circ} \mathrm{C} / \mathrm{min}$ and holding of one hour at each temperature followed by quenching in water at the 
end of the treatment. The second heat treatment was performed keeping the same holding times but changing the treatment temperatures, namely 600,1020 and $1050^{\circ} \mathrm{C}$ followed by quenching in water. In this case, the heating rate was fixed at $12^{\circ} \mathrm{C} / \mathrm{min}$. The used heat treatments cycles for studied steels are shown in Fig. 1.

\subsection{Sample Preparation for Microstructure Investigation}

For metallographic characterizations, all the samples, as-casting and heat treated, were polished and chemically etched with Nital $4 \%$. The microstructure analysis was carried out using a metallurgical optical microscope (MOM) and a scanning electron microscope (SEM) equipped with an energy dispersive X-ray (EDX). The average grain size was determined using ImageJ software. The X-Ray diffractions (XRD) studies were carried out using a Rigaku type diffractometer with a $\mathrm{Cu} K_{\alpha}$ radiation $(\lambda=1.5406 \AA)$ within the angle $2 \theta$ range of $20^{\circ}$ to $100^{\circ}$ with a step size of $0.02^{\circ}$ and a collection time of $10 \mathrm{~s}$. The diffraction patterns were adjusted using X'Pert HighScore Plus software.

\subsection{Mechanical Proprieties}

The behaviour wear of studied steels was estimated by comparing the values of wear resistance, Rockwell C hardness (applied load of 150 $\mathrm{kgf}$ ) and Vickers microhardness (applied load of $200 \mathrm{gf}$ ) and friction coefficient.

The abrasive wear tests were conducted on all the samples using the pin-on-disk method at room temperature. The test was performed using an applied normal load of $300 \mathrm{~N}$ and rotation speed of $200 \mathrm{~min}^{-1}$
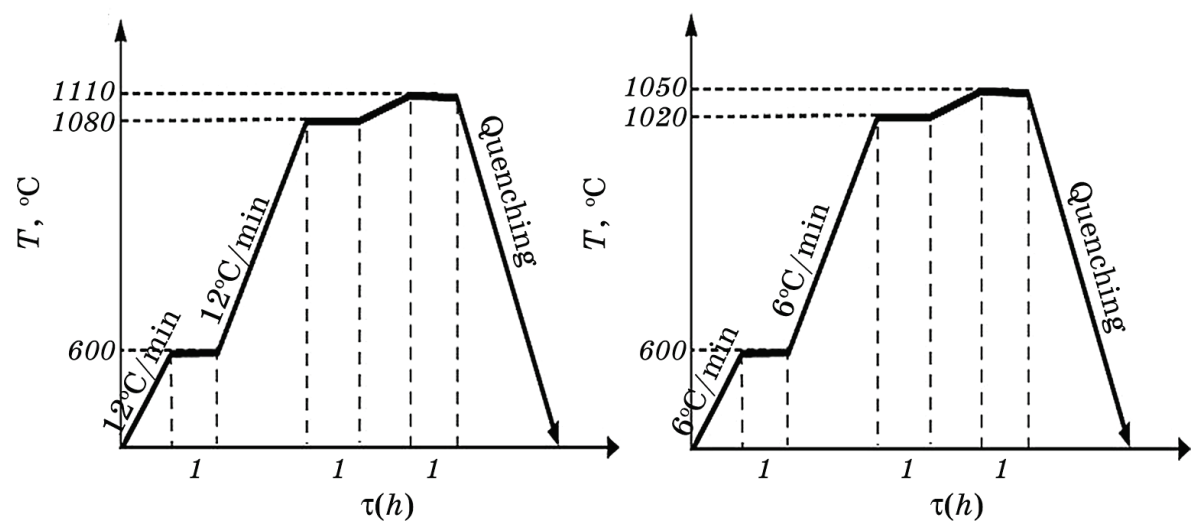

Fig. 1. Heat treatments cycles. 
over a sliding distance of $1000 \mathrm{~m}$ on a fresh 120 grit $\mathrm{SiC}$ abrasive paper without stopping the test. Before each test, the samples were cleaned with alcohol. The mass loss of specimens was measured using an analytical balance with an accuracy of $0.1 \mathrm{mg}$. The wear abrasion rate was estimated from the following equation [20]:

$$
W_{\mathrm{r}}=D P S / \Delta m,
$$

where $W_{\mathrm{r}}$ is the wear resistance, $D$ is the density, $P$ is the applied load, $S$ is the sliding distance, and $\Delta m$ is the mass loss. The density of Hadfield steel is $7200 \mathrm{~kg} / \mathrm{m}^{3}$.

For determining the variation of friction coefficient before and after the heat treatment of specimens, two wear tests were performed using a ball-on-disk apparatus under two loads $(6 \mathrm{~N}$ and $10 \mathrm{~N})$ at 0.5 $\mathrm{m} / \mathrm{s}$ sliding speed and $100 \mathrm{~m}$ sliding distance. The ball specimen was made of steel 100Cr6 with a diameter of $6 \mathrm{~mm}$ and hardness of $61 \mathrm{HRC}$. Before the test, the samples were ground with abrasive paper (grit 2400), polished and cleaned with alcohol.

\section{RESULTS AND DISCUSSIONS}

Chemical compositions of the cast steels used in this study are determined using the energy dispersive spectroscopy and listed in Table 1.

\subsection{Microstructure Analysis}

Figure 2 shows the optical micrographs of the as-cast studied steels (A1, A2 and A3). In this state, the microstructure of steels alloyed with $\mathrm{Cr}+\mathrm{Ni}$ consists of an austenitic matrix enriched in $\mathrm{Mn}$ and complex carbides precipitated at the grain boundaries. Intergranular not uniformed precipitates have been also observed. During cooling after solidification, the solubility of carbon and manganese in austenite decreases and the carbon and manganese rejected from the solid solution are precipitated as secondary carbides ( $\mathrm{Mn}$ alloyed cementite) within

TABLE 1. Chemical compositions of the studies steels ( $\%$ mass).

\begin{tabular}{c|c|c|c|c|c|c|c}
\hline \multirow{2}{*}{ Sample } & \multicolumn{7}{|c}{ Chemical composition, \% wt. } \\
\cline { 2 - 8 } & $\mathrm{C}$ & $\mathrm{Mn}$ & $\mathrm{Si}$ & $\mathrm{P}$ & $\mathrm{S}$ & $\mathrm{Cr}$ & $\mathrm{Ni}$ \\
\hline $\mathrm{A} 1$ & 1.266 & 11.88 & 0.434 & 0.051 & 0.008 & 1.05 & 0.17 \\
$\mathrm{~A} 2$ & 1.318 & 11.77 & 0.594 & 0.057 & 0.008 & 1.17 & 0.26 \\
$\mathrm{~A} 3$ & 1.256 & 11.61 & 0.616 & 0.057 & 0.011 & 1.79 & 0.47 \\
\hline
\end{tabular}


the austenite grains. The XRD pattern of sample A1 confirmed the existence of this carbides as (Fe, Mn) ${ }_{3} \mathrm{C}$ in this type of steels (Fig. 3). The added chromium comes along with iron and manganese to form a complex carbide $(\mathrm{Fe}, \mathrm{Mn}, \mathrm{Cr})_{3} \mathrm{C}$.

The size of austenitic grains and the amount of precipitated carbides are influenced by the nature and the content of added elements. The grain size decreases with increasing of $\mathrm{Cr}+\mathrm{Ni}$ addition (Fig. 4). $\mathrm{Be}$ added as the austenite stabilizing element, nickel with its small amount does not change the microstructure of the as-cast Hadfield steel [21]. Carbide forming elements, such as chromium, enhance the formation of the complex carbide $\left((\mathrm{Fe}, \mathrm{Mn}, \mathrm{Cr})_{3} \mathrm{C}\right)$, which blocks the growth of the austenite grain and refines the structure.

The intergranular precipitation decreases with increasing $\mathrm{Cr}+\mathrm{Ni}$ content and the high fraction of carbides was noticeable at the grain boundaries. Based on the quantitative data of EDX analysis (Fig. 5), it can be stated that the intergranular precipitate (point 1 ) is the $\mathrm{Mn}$ -
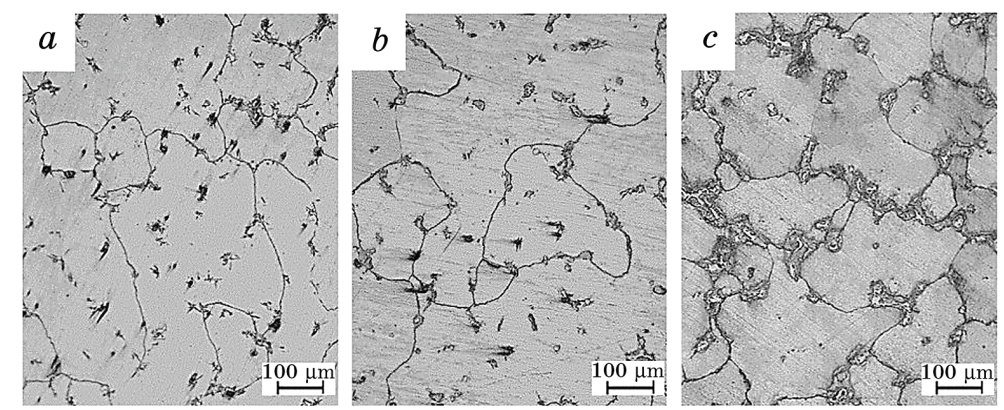

Fig. 2. Optical micrographs of the as-cast studied steels: sample A1 (a), sample A2 (b), sample A3 (c).

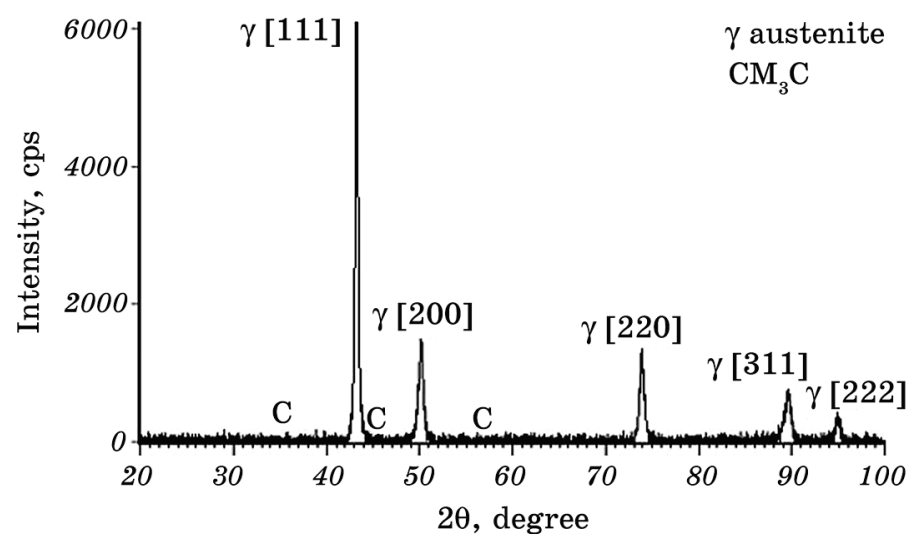

Fig. 3. XRD pattern of the simple A1 in the as cast state. 
alloyed cementite $\left((\mathrm{Fe}, \mathrm{Mn})_{3} \mathrm{C}\right)$. This analysis allows also the identification of $(\mathrm{Mn}, \mathrm{Cr})$ alloyed cementite $\left((\mathrm{Fe}, \mathrm{Mn}, \mathrm{Cr})_{3} \mathrm{C}\right)$ at the grain boundary (point 2).

The effect of chromium content on the morphology of alloyed cementite in the studied steel in its as-cast state is shown in Fig. 6. The fraction of the alloyed cementite precipitates $\left((\mathrm{Fe}, \mathrm{Mn}, \mathrm{Cr})_{3} \mathrm{C}\right)$ increases with increasing of $\mathrm{Cr}$ content.

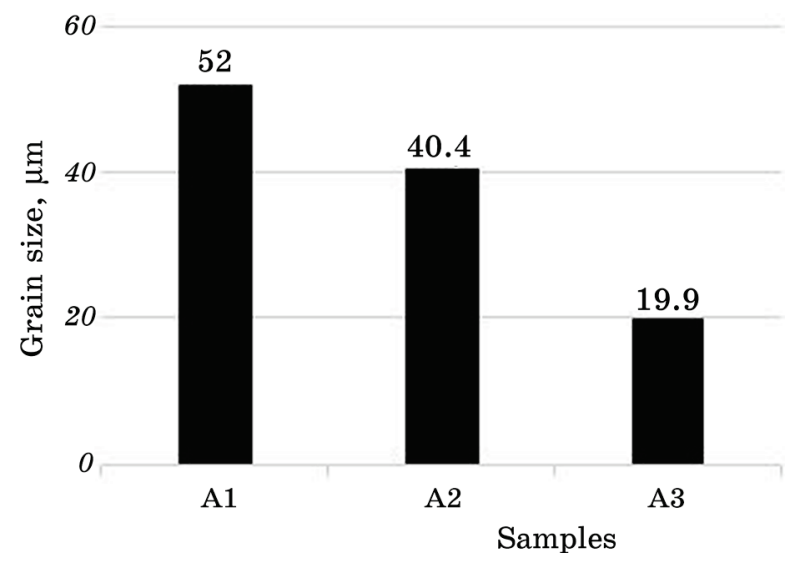

Fig. 4. Sizes of the austenitic grains in the as-cast studied steels.

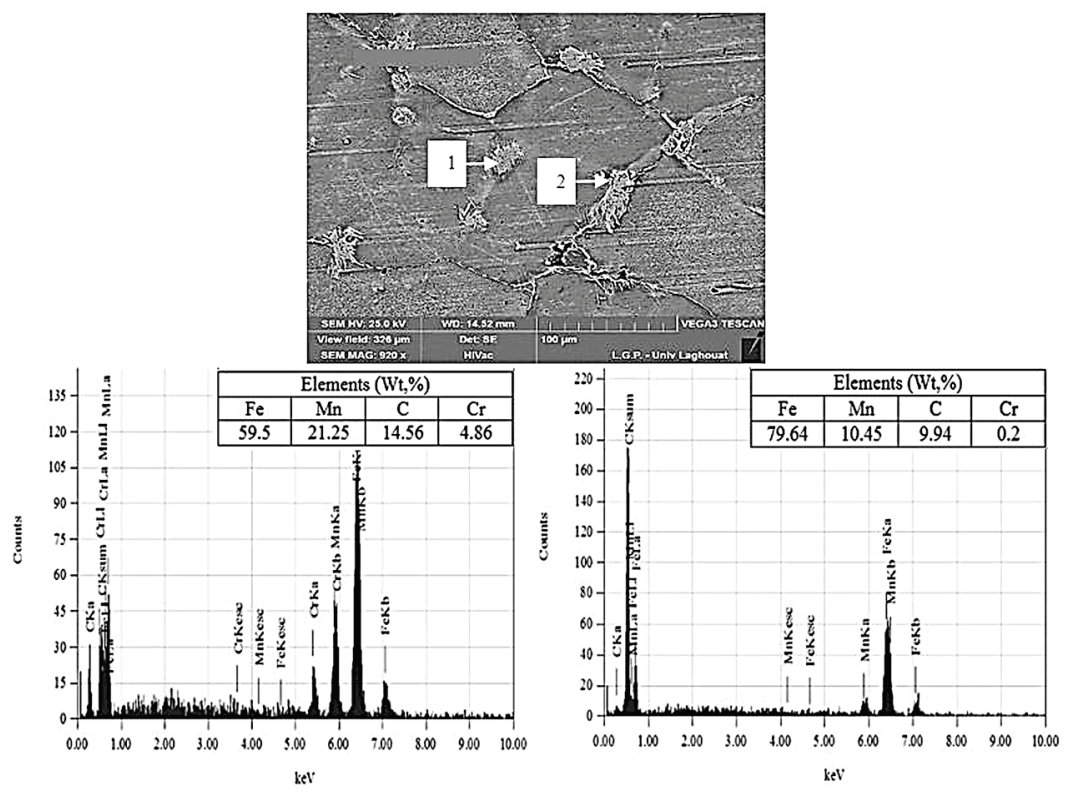

Fig. 5. EDX spectrum of alloyed cementite: $1-(\mathrm{Fe}, \mathrm{Mn})_{3} \mathrm{C}, 2-(\mathrm{Fe}, \mathrm{Mn}, \mathrm{Cr})_{3} \mathrm{C}$. 

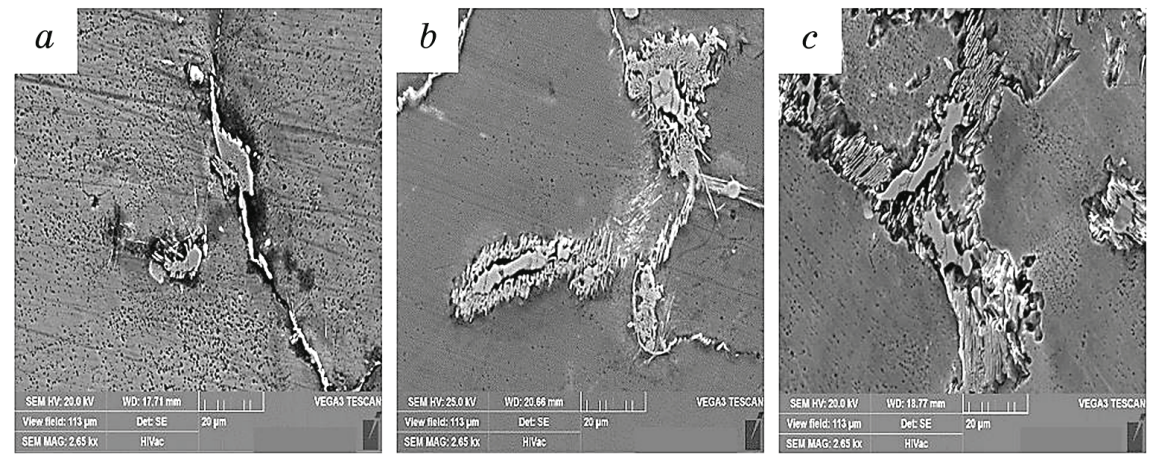

Fig. 6. SEM micrographs of alloyed cementite (Fe, $\mathrm{Mn}, \mathrm{Cr})_{3} \mathrm{C}$ : sample $\mathrm{A} 1(a)$, sample A2 (b), sample A3 (c).

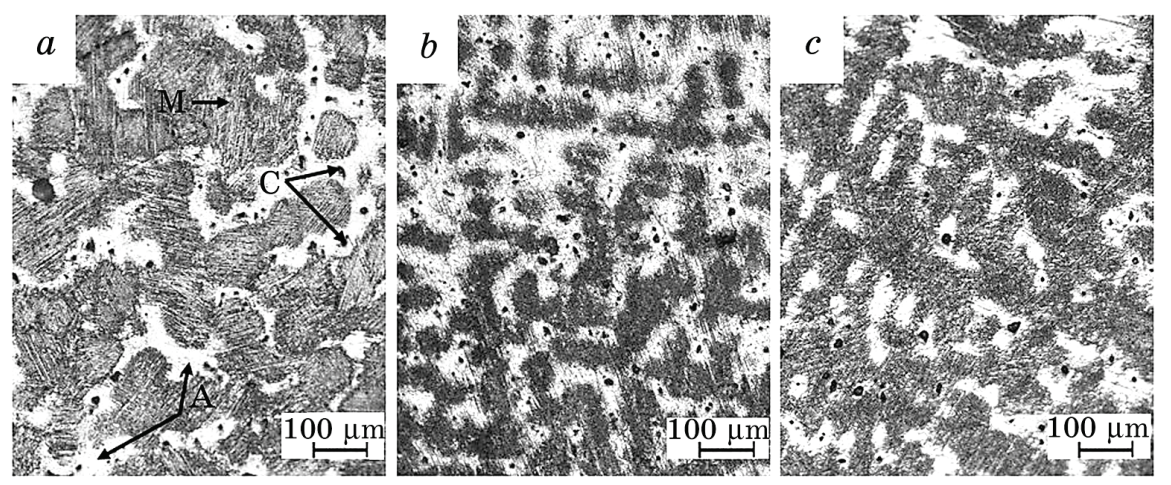

Fig. 7. Optical micrographs of studied steels after heat treatment at $1050^{\circ} \mathrm{C}$ : sample A1 (a), sample A2 (b), sample A3 (c).
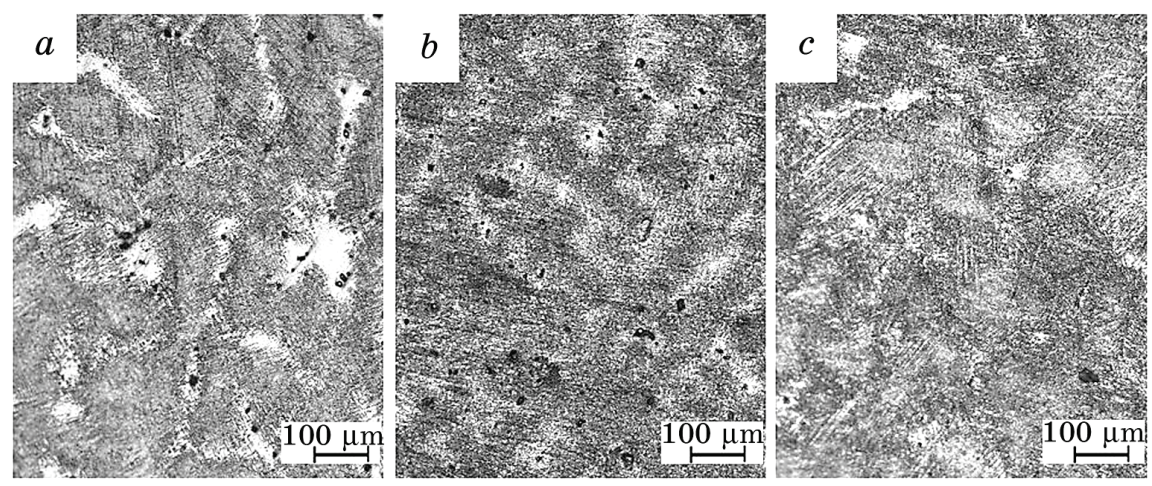

Fig. 8. Optical micrographs of studied steels after heat treatment at $1100^{\circ} \mathrm{C}$ : sample A1 (a), sample A2 (b), sample A3 (c). 
The optical micrographs of the studied steels after heat treatment at $1050^{\circ} \mathrm{C}$ and $1100^{\circ} \mathrm{C}$ are illustrated in Figs. 7 and 8, respectively. After heat treatments, their micrographic structure consists of two phases: the martensite (M) and the residual austenite (A). The martensitic phase comes in a dendrite form by the two heat treatments. The main and secondary arms of theses dendrites vary with the chromium and nickel content and the used heat treatments. The increase of $\mathrm{Cr}+\mathrm{Ni}$ content promotes the transformation of austenite to martensite. This is explained by the hardening effect of these elements. Nickel has only a moderate effect on the hardenability of steels. Chromium, on the other hand, is known for its positive influence on this characteristic. For a medium carbon steels and after water quenching, martensite appears even at low chromium percentages. The increasing of chromium content allows the austenite to transform into martensite even for air cooling. During rapid cooling (in water or hyperquenching), chromium and nickel accelerate the hardening of the steel, which justifies the increase of the martensitic phase of A3 steel after the used heat treatments in comparison with A2 and A1.

Figure 9 presents the XRD pattern of sample A1 after heat treatments at $1050^{\circ} \mathrm{C}$ and $1100^{\circ} \mathrm{C}$. A reduction in the intensity and number of austenitic peaks and increase of those of martensite are observed for the heat treatment at $1100^{\circ} \mathrm{C}$ in comparison with that at $1050^{\circ} \mathrm{C}$. A heating to $1100^{\circ} \mathrm{C}$ with a holding time of one hour promotes greater decomposition of carbides than a warm-up to $1050^{\circ} \mathrm{C}$, which would allow a greater dissolution of the chemical elements in the austenite. This accelerates the diffusionless transformation and would favour the martensitic phase. Better carbide dissolution reduces the critical hardenability rates.
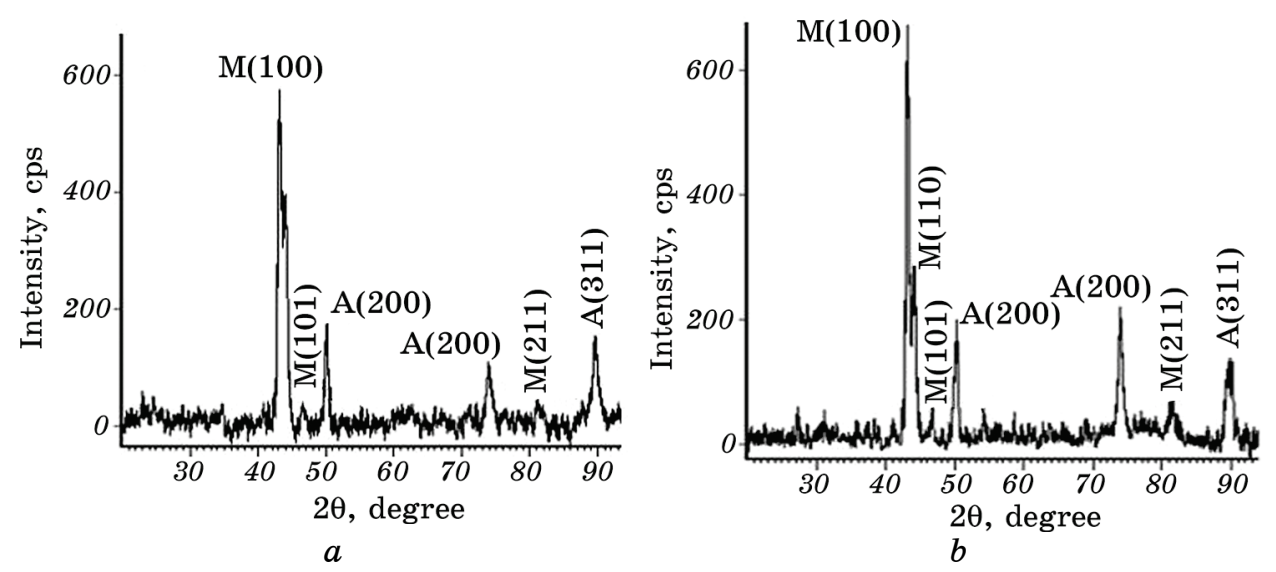

Fig. 9. XRD patterns of sample A1 after heat treatments at $1050^{\circ} \mathrm{C}(a)$ and $1100^{\circ} \mathrm{C}(b)$. 
A small amount of undissolved cementite (C) was also observed in the austenitic phase. Conventionally, heat treatments of Hadfield steel at a temperature of 1000 to $1100^{\circ} \mathrm{C}$ dissolve the $(\mathrm{Fe}, \mathrm{Mn})_{3} \mathrm{C}$ carbide in the austenite and the following quenching in water will hinder the formation of $\mathrm{M}_{3} \mathrm{C}$ carbides [22]. The microstructure observations (Fig. 7 ) show that the used heat treatment at $1050^{\circ} \mathrm{C}$ does not have a significant effect on carbides dissolution. The amount of carbide distributed in the austenitic matrix after heat treatment at $1100^{\circ} \mathrm{C}$ is smaller than that precipitated after heat treatment at $1050^{\circ} \mathrm{C}$. As a result, the heat treatment at $1100^{\circ} \mathrm{C}$ has a more significant effect on dissociation of secondary precipitation than that at $1050^{\circ} \mathrm{C}$.

\subsection{Hardness}

Rockwell C hardness (HRC) and Vickers microhardness values of all the samples in the as-cast and heat-treated states are presented in Fig. 10 (unacceptable quality) and Table 2 , respectively.

Figure 10 shows that in the as cast conditions the hardness of sample A3 is higher than that of sample A2 and sample A1 due to refinement of austenitic grain and increasing of volume fraction of the alloyed cementite in the microstructure. In this state, the grain boundary alloyed cementite acts as a hard phase in the ductile austenitic matrix and increases the total hardness of the studied steel.

After heat treatment, sample A3 showed a considerable increase of hardness in comparison with sample A2 and sample A1. This is related to the increase of $\mathrm{Cr}+\mathrm{Ni}$ content, hardening elements, which increases the formation of martensitic phase and also assists the dissolution of carbon, manganese and chromium elements in the $\gamma$-iron lattice, which strengthens the retained austenite. The heat treatment at $1050^{\circ} \mathrm{C}$ has a smaller influence on hardness change in the studied steels compared to that at $1100^{\circ} \mathrm{C}$, which dissolves more the precipitates and favours the formation of martensite. Microhardness measurements (610-780

TABLE 2. Vickers microhardness of the studied steels before and after heat treatments.

\begin{tabular}{c|cc|c|c|c|c}
\hline \multirow{2}{*}{ Sample } & \multicolumn{2}{|c|}{ As-cast } & \multicolumn{2}{c|}{$\begin{array}{c}\text { Heat treated at } \\
1050^{\circ} \mathrm{C}\end{array}$} & \multicolumn{2}{|c}{$\begin{array}{c}\text { Heat treated at } \\
1100^{\circ} \mathrm{C}\end{array}$} \\
\cline { 2 - 7 } & $\begin{array}{c}\text { Austenitic } \\
\text { matrix }\end{array}$ & $\begin{array}{c}\text { Alloyed } \\
\text { cementite }\end{array}$ & Martensite & $\begin{array}{c}\text { Retained } \\
\text { austenite }\end{array}$ & Martensite & $\begin{array}{c}\text { Retained } \\
\text { austenite }\end{array}$ \\
\hline A1 & 249 & 1120 & 610 & 265 & 649 & 285 \\
A2 & 273 & 1200 & 674 & 290 & 718 & 315 \\
A3 & 312 & 1327 & 723 & 350 & 780 & 379 \\
\hline
\end{tabular}


$\mu \mathrm{HV}_{20}$ ) confirmed the existence of martensitic phase after heat treatments (Table 2).

\subsection{Wear Resistance}

Figure 11 shows the mass loss and wear resistance of all the samples in their as-cast states and after heat treatments. Sample A3 has a higher wear resistance than samples A2 and A1 for all states (as-cast ones and

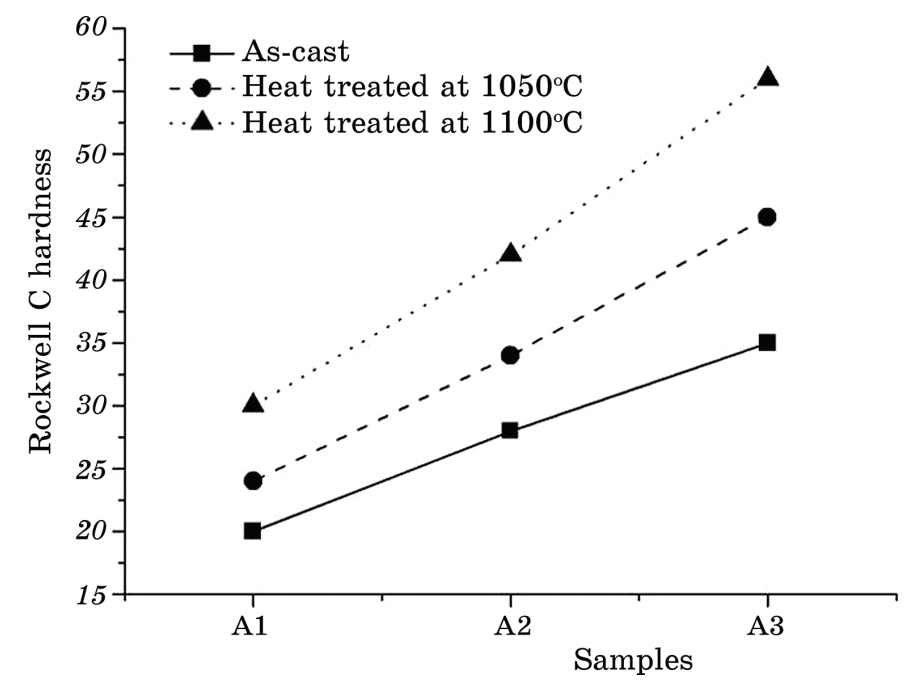

Fig. 10. Rockwell C hardness of the studied steels.
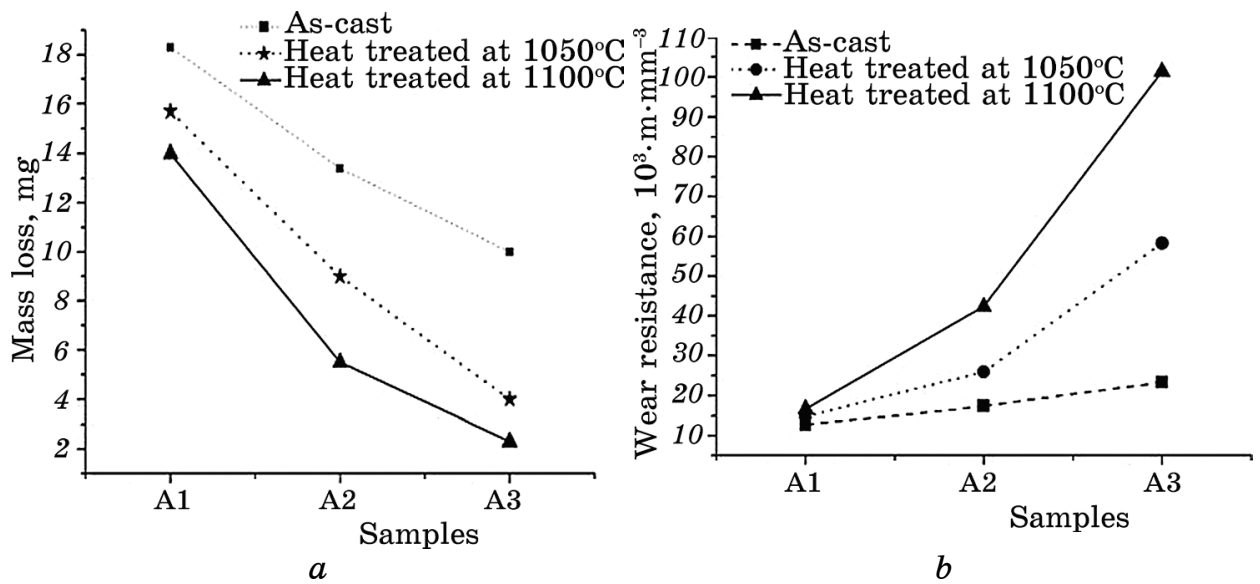

Fig. 11. Mass loss $(a)$ and wear resistance $(b)$ of the studied steels in as-cast stat and after heat treatments. 
after heat treatments). It is seen that the mass loss of the sample A3 with the hardness of $34 \mathrm{HRC}$ is smaller than that of sample A2 with hardness of 26 HRC and sample A1 with 20 HRC. The wear resistance increases linearly with hardness. A reason for that is the presence of coarse carbides in the matrix of sample A3. Likewise, the mass loss of the studied Hadfield steels decreases as $\mathrm{Cr}+\mathrm{Ni}$ content increases. After heat treatments, the excellent wear resistance of the studied Hadfield steels could be explained by the transformation of austenite to martensite, which results in the hardening of steel surface and the increase of wear resistance.

\subsection{Friction Coefficient}

The friction coefficient of the studied steels for the two loads before and after heat treatments is given in Fig. 12 and Table 3. In as-cast states and for the applied load of $10 \mathrm{~N}$, the stability of the friction coefficient has been marked after a sliding distance of $20 \mathrm{~m}$ for the sample A1, $40 \mathrm{~m}$ for the sample A2 and about $80 \mathrm{~m}$ for sample A3. In addition, the fluctuation of friction coefficient of the sample A3 was more than that of sample A1 and sample A2. This fact is due to the existence
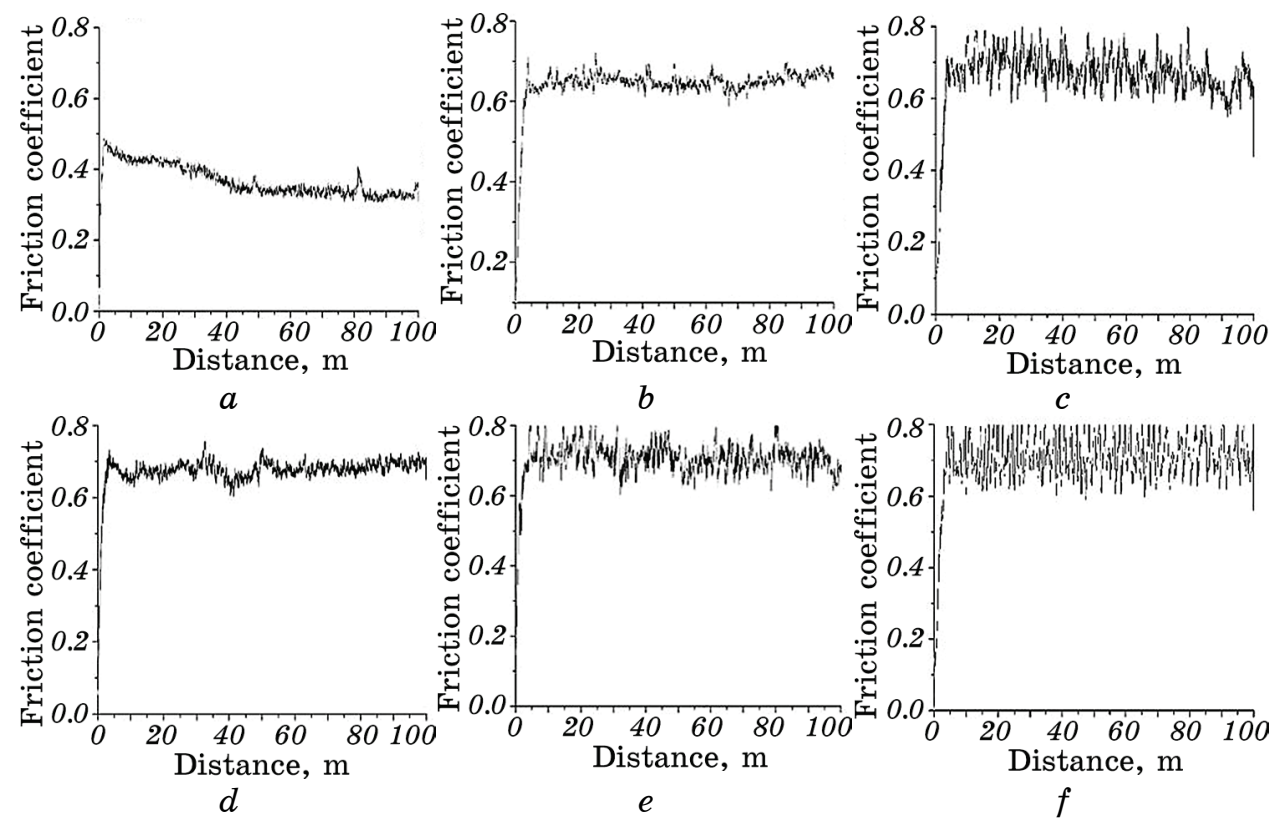

Fig. 12. Friction coefficient of the as-cast studied steels: sample A1 ( $3 \mathrm{~N})(a)$, sample A2 (3N) $(b)$, sample A3 (3N) $(c)$, sample A1 (10 N) $(d)$, sample A2 $(10 \mathrm{~N})(e)$, sample A3 $(10 \mathrm{~N})(f)$. 
TABLE 3. Friction coefficients of the studied steels.

\begin{tabular}{c|c|c|c|c|c|c}
\hline \multirow{2}{*}{ Sample } & \multicolumn{3}{|c|}{$3 \mathrm{~N}$} & \multicolumn{3}{c}{$10 \mathrm{~N}$} \\
\cline { 2 - 7 } & As-cast & $\begin{array}{c}\text { Heat } \\
\text { treated at } \\
1050^{\circ} \mathrm{C}\end{array}$ & $\begin{array}{c}\text { Heat } \\
\text { treated at } \\
1100^{\circ} \mathrm{C}\end{array}$ & $\begin{array}{c}\text { Heat } \\
\text { As-cast } \\
\text { treated at } \\
1050^{\circ} \mathrm{C}\end{array}$ & $\begin{array}{c}\text { Heat } \\
\text { treated at } \\
1100^{\circ} \mathrm{C}\end{array}$ \\
\hline $\mathrm{A} 1$ & 0.366 & 0.492 & 0.529 & 0.590 & 0.602 & 0.617 \\
$\mathrm{~A} 2$ & 0.606 & 0.634 & 0.647 & 0.638 & 0.648 & 0.705 \\
$\mathrm{~A} 3$ & 0.669 & 0.675 & 0.681 & 0.706 & 0.723 & 0.736 \\
\hline
\end{tabular}

of a large amount of coarse secondary carbides $\left((\mathrm{Fe}, \mathrm{Mn}, \mathrm{Cr})_{3} \mathrm{C}\right)$. The stability of the friction coefficient can be related to the deformation of this carbide under the high applied load. As it was described in previous paragraphs, the increased heat treatment temperature dissolves more secondary carbides and enhances the formation of martensite, which improves hardness, wear resistance and, consequently, the friction coefficient.

The increase of applied load from $3 \mathrm{~N}$ to $10 \mathrm{~N}$ improves the friction coefficient of all the samples. This result can be explained by the work hardening phenomenon during the test.

\section{CONCLUSIONS}

1. The as-cast microstructure of $\mathrm{Cr}+\mathrm{Ni}$ alloyed Hadfield steel consists of an austenitic matrix and $\mathrm{Mn}-\mathrm{Cr}$ alloyed cementite $\left((\mathrm{Fe}, \mathrm{Mn}, \mathrm{Cr})_{3} \mathrm{C}\right)$ precipitated at grain boundaries.

2. The increase of the $\mathrm{Cr}+\mathrm{Ni}$ content increases the amount of the alloyed grain boundary cementite, which leads to refinement of structure and improves the hardness and wear resistance. Existence of these coarse carbide particles enhances the oscillation of the friction coefficient.

3. The microstructure of the heat treated studied steels consists of two phases: martensite and non-transformed austenite. The increased amount of $\mathrm{Cr}+\mathrm{Ni}$ soaking elements favours the transformation of austenite to martensite.

4. After heat treatment at $1050^{\circ} \mathrm{C}$, in addition to these two phases, the microstructure reveals a small amount of the undissolved carbides. Therefore, the heat treatment at $1050^{\circ} \mathrm{C}$ cannot dissolve all $\mathrm{Mn}-\mathrm{Cr}$ alloyed cementite.

5. The increasing of heat treatment temperature and decrease of heating rate act positively on dissolution of secondary carbides and martensitic transformation, which improves significantly the hardness, wear resistance and friction coefficient of $\mathrm{Cr}+\mathrm{Ni}$ modified Hadfield steel. 
6. The friction coefficient raises with increasing applied load.

\section{REFERENCES}

1. V. G. Gavriljuk, A. I. Tyshchenko, O. N. Razumov, Yu. N. Petrov, B. D. Shanina, and H. Berns, Materials Science and Engineering A, 420: 47 (2006).

2. A. Nasajpour, A. H. Kokabi, P. Davami, and S. Nikzad, J.Alloys and Compounds, 659: 262 (2016).

3. R. Harzallah, A. Mouftiez, E. Felder, S. Hariri, and J. P. Maujean, Wear, 269: 647 (2010).

4. S. A. Balogun, D. E. Esezobor, and J. O. Agunsoye, J. Minerals and Materials Characterization and Engineering, 7, No. 3:, 277 (2008).

5. P. C. Machado, J. I. Pereira, J. J. Penagos, T. Yonamine, and A. Sinatora, Wear, 376-377: 1064 (2017).

6. G. Tęcza and S. Sobula, Archives of Foundry Engineering, 14: 67 (2014).

7. X. Y. Feng, F. C. Zhangn, Z. N. Yang, and M. Zhang, Wear, 305: 299 (2013).

8. D. Siafakas, T. Matsushita, A. Lauenstein, J. Ekengard, and E. W. Jarfors, Metals, 7: 186 (2017).

9. P. Chowdhury, D. Canadinc, and H. Sehitoglu, Materials Science and Engineering R, 122: 1 (2017).

10. R. Sinha and A. K. Mukhopadhyay, Materials Research, 20 (4): 1153 (2017).

11. Y. Feng, R. Song, S. Peng, C. Cai, and Z. Tan, Materials Science Forum, 898: 766 (2017).

12. J. M. Pelletier, E. Sauger, Y. Gachon, and A. B. Vannes, Materials Science, 34: 2955 (1999).

13. K. N. Vdovin, D. A. Gorlenko, N. A. Feoktistov, Metal Science and Heat Treatment, 59, Nos. 3-4: (2017).

14. Sh. Hosseini, M. B. Limooei, M. Hossein Zade, E. Askarnia, and Z. Asadi, Materials and Metallurgical Engineering, 7, No. 7: 582 (2013).

15. J. O. Agunsoye, S. I. Talabi, and O. Bello, Advances in Production Engineering and Management, 10, No. 2: 97 (2015).

16. H. Maouche, A. Hadji, and K. Bouhamla, Metallurgical and Mining Industry, No. 3: 75 (2016).

17. A. Gharbi, H. Maouche, and O. Ghelloudj, Acta Physica Polonica A, 131, No. 3: 346 (2017).

18. L. G. Korshunov, I. I. Kositsina, V. V. Sagaradze, and N. L. Chernenko, Physics of Metals and Metallography, 112, No. 1: 90 (2011).

19. Y. Zhang, J. Li , C. B. Shi, Y. F. Qi, and Q. T. Zhu, Metals, 7, Iss. 3: 94: (2017).

20. M. M. Atabaki, S. Jafari, and H. Abdollah-pour, J. Iron and Steel Research International, 19, No. 4: 43 (2012).

21. B. Kalandyk, G. Tęcza, R. Zapała, and S. Sobula, Archives of Foundry Engineering, 15: 35 (2015).

22. E. G. Moghaddam, N. Varahram, and P. Davami, Materials Science and Engineering A, 532: 260 (2012). 